\title{
PENGARUH COGNITIVE BEHAVIOR THERAPY TERHADAP PENURUNAN TINGKAT KEKAMBUHAN HALUSINASI PADA PASIEN HALUSINASI DENGAR
}

\author{
The Effect of Cognitive Behavior Therapy on Decreasing Levels of Hallucinations \\ Recurrence in Hearing Hallucinations Patient
}

\author{
Claudia Wuri Prihandini ${ }^{1}$, Ni Komang Matalia Gandari ${ }^{2}$, Ni Wayan Bunter ${ }^{3}$ \\ ${ }^{I}$ Departemen Keperawatan Jiwa, STIKES Bina Usada Bali, Badung, Bali, Indonesia \\ ${ }^{21}$ Departemen Keperawatan Komunitas Keluarga dan Gerontik, STIKES Bina Usada Bali, Badung, Bali, Indonesia \\ ${ }^{2}$ Mahasiswa Sarjana Keperawatan, STIKES Bina Usada Bali, Badung, Bali, Indonesia \\ Korespondensi : claudiaprihandini@gmail.com
}

\begin{abstract}
ABSTRAK
Halusinasi adalah merasakan segala sesuatu dalam keadaan sadar yang tampak nyata, namun sebenarnya hanya diciptakan oleh persepsi pikiran sendiri. Pasien dengan halusinasi pendengaran jika tidak segera ditangani akan berakibat kehilangan kontrol seperti bunuh diri, membunuh, bahkan merusak lingkungan. Terapi keperawatan yang direkomendasikan adalah Cognitive Behaviour Therapy (CBT). Adapun tujuan dari penelitian ini adalah untuk mengetahui pengaruh CBT terhadap penurunan tingkat kekambuhan halusinasi pada pasien halusinasi dengar. Penelitian ini menggunakan desain one group pre test post test dengan jumlah sampel sebanyak 63 orang dengan menggunakan teknik sampling purposive. Instrumen untuk mengumpulkan data menggunakan instrumen Psychotic Syndrome Rating Scale. Data dianalisis dengan uji paired-t. Berdasarkan hasil penelitian diatas dapat disimpulkan pemberian terapi CBT memberi pengaruh yang signifikan secara statistik terhadap tingkat kekambuhan halusinasi pada pasien dengan halusinasi dengar dengan nilai signifikansi sebesar 0,000.
\end{abstract}

Kata kunci : cognitive behavior therapy; halusinasi; tingkat kekambuhan

\begin{abstract}
Hallucinations are the feeling of everything in a conscious state that identified as real experience, however, it is actually only created by the perception of the mind itself. If patients with auditory hallucinations were not treated immediately it will lead to suicide, murder, and environmental suspect. The nursing therapy which is recommended in an effort to overcome hallucinations is Cognitive Behavior Therapy (CBT). The purpose of this study is to determine the effect of CBT on reducing the level of hallucinatory recurrence in hearing hallucinatory patients. This study applied one group pre test post test design, which is with a sample of 63 people using purposive sampling. Data were collected by using the Psychotic Syndrome Rating Scale instrument. Following this, data were analyzed by the paired t-test. According to the results of the study and analysis, it can be concluded that the provision of CBT therapy has significantly influenced the level of recurrence of hallucinations on patients with auditory hallucinations with a significance value 0,000.
\end{abstract}

Keywords : cognitive behavior therapy (CBT); hallucinations; recurrence 
Claudia Wuri P., dkk : Pengaruh Cognitive Behavior Therapy Terhadap Penurunan Tingkat Kekambuhan Halusinasi Pada Pasien Halusinasi Dengar

\section{PENDAHULUAN}

Berdasarkan data World Health
Organization (WHO) tahun 2017, diperkirakan 300 juta orang mengalami depresi, 60 juta orang mengalami bipolar, 21 juta orang mengalami masalah psikosis dan skizofrenia (WHO, 2017). Hal ini menunjukan bahwa masalah gangguan jiwa di dunia ini sudah menjadi masalah yang semakin serius dengan terus bertambahnya prevalensi gangguan kejiwaan. Yosep (2009) mengatakan lebih dari $90 \%$ pasien dengan skizofrenia mengalami halusinasi pendengaran, penglihatan, penciuman dan pengecapan. Halusinasi merupakan sebuah bentuk keadaan yang merasakan segala sesuatu tampak nyata, namun sebenarnya hanya diciptakan oleh persepsi pikiran sendiri (Beck, 2011). Halusinasi merupakan perubahan sensori dimana pasien merasakan sensasi yang tidak ada berupa suara, penglihatan, pengecapan dan perabaan (Damaiyanti \& Iskandar, 2012).

Halusinasi pendengaran sangat umum terjadi pada penderita skizofrenia (Adrian, 2016). Halusianasi dengar juga dapat terjadi pada penderita gangguan mental lain seperti gangguan bipolar, gangguan kepribadian ambang, depresi berat dengan gangguan stress pascatrauma (Yosep, 2009). Kondisi skizofrenia mempengaruhi otak sebagai bentuk dari psikosa fungsional yang menyebabkan timbulnya pikiran, persepsi, emosi, gerakan, perilaku aneh dan terganggu. Gangguan ini mengakibatkan disharmoni antara proses pikir, afek, kemauan dan psikomotor disertai distorsi kenyataan terutama karena waham dan halusinasi, yang mengakibatkan timbul inkoherensi (Stuart \& Laraia, 2009).

Orang dengan masalah halusinasi pendengaran jika tidak segera ditangani akan memberi dampak yang sangat buruk bagi dirinya sendiri, orang lain, atau lingkungan sekitarnya. Pasien akan mengalami panik dan dikendalikan oleh halusinasinya. Pada situasi ini pasien dapat mengalami resiko bunuh diri (suicide), membunuh orang lain (homicide), bahkan merusak lingkungan. Untuk mengurangi gejala dapat dilakukan intervensi berupa cognitive behavior therapy (CBT) (Komalasari, Wahyuni, \& Karsih, 2011).
CBT merupakan sebuah terapi yang digunakan untuk memodifikasi fungsi berpikir dan bertindak yang menekankan pada peran otak dalam menganalisa, bertanya, berbuat dan memutuskan kembali serta merubah status pikiran dan perasaan. Pemberian CBT dilakukan oleh psikiater dan perawat jiwa yang telah tersertifikasi. Pemberian CBT terbukti memberikan perubahan pada pasien dengan halusinasi dan waham (Kaplan \& Saddock, 2010). Keefektifan terapi ini telah dibuktikan penelitian Granholm, Holden, Link, \& McQuaid (2014), mengungkapkan bahwa dengan CBT pada pasien skizofrenia kronis dapat mengurangi halusinasi dan juga delusi. CBT dapat memperkuat keyakinan dan kemampuan pasien dalam mengontrol halusinasi secara konsisten melalui strategi koping yang baik (Sarandria, 2012).

\section{TUJUAN PENELITIAN}

Penelitian ini bertujuan untuk mengetahui pengaruh cognitive behavior therapy terhadap penurunan tingkat kekambuhan halusinasi pada pasien halusinasi dengar.

\section{METODE PENELITIAN}

Desain

Desain penelitian yang digunakan sebagai adalah one group pre test post test.

\section{Populasi dan Sampel}

Populasi penelitian ini adalah semua pasien dengan halusinasi pendengaran di Rumah Sakit Angkatan Darat Udayana sebanyak 75 orang. Jumlah sampel dalam penelitian ini adalah 63 orang, dengan kriteria bersedia diteliti; pasien yang belum pernah mendapatkan terapi CBT. Teknik pengambilan sampel menggunakan teknik purposive.

\section{Tempat dan Waktu Penelitian \\ Penelitian ini dilakukan Poliklinik Jiwa RSAD Udayana pada bulan November 2018 sampai dengan Februari 2019.}


Claudia Wuri P., dkk : Pengaruh Cognitive Behavior Therapy Terhadap Penurunan Tingkat Kekambuhan Halusinasi Pada Pasien Halusinasi Dengar

\section{Intervensi}

Intervensi pada penelitian ini yaitu dengan memberikan perlakuan CBT dimana tindakan ini dilakukan selama 8 sesi. Sesi 1 mengkaji pemicu halusinasi, sesi 2 mengontrol halusinasi, sesi 3-5 melatih Teknik yang sudah diberikan, sesi 6-7 tentang self control desensitisasi dan sesi 8 melakukan relaksasi. Masing-masing sesi dilakukan setiap seminggu sekali dan lama tiap sesi adalah 1,5 jam.

\section{Instrumen dan Prosedur Pengukuran}

Peneliti berpedoman dengan standar operating procedure CBT ketika memberikan perlakuan kepada responden.
Setelah diberikan intervensi selama 8 sesi, peneliti memberikan skoring 1-10 pada intensitas kekambuhan yang muncul dengan menggunakan instrument kuisioner Psychotic Syndrome Rating Scale (PSYRAT).

\section{Analisa Data}

Analisa univariat dilakukan pada data karakteristik demografi responden. Analisa bivariat dilakukan dengan menggunakan paired t-test.

\section{HASIL PENELITIAN}

Berikut ini akan dijelaskan hasil pengumpulan data penilitian yang telah dilakukan selama 8 minggu, yaitu:

Tabel 1.

Karakteristik Responden $(\mathrm{n}=63)$

\begin{tabular}{lcc}
\hline \multicolumn{1}{c}{ Variabel } & Frekuensi (f) & Persentase (\%) \\
\hline Usia & & \\
$<25$ tahun & 14 & 18 \\
$25-35$ tahun & 16 & 21 \\
35-45 tahun & 20 & 26 \\
$45-55$ tahun & 18 & 24 \\
$>55$ tahun & 8 & 11 \\
\hline Jenis Kelamin & & \\
Laki-Laki & 38 & 50 \\
Perempuan & 38 & 50 \\
\hline Pendidikan & & \\
Tidak Sekolah & 3 & 20 \\
SD & 15 & 26 \\
SMP & 20 & 42 \\
SMA/SMK & 32 & 8 \\
Perguruan Tinggi & 6 & 29 \\
\hline Status Perkawinan & & 64 \\
Belum Kawin & 22 & 4 \\
Kawin & 49 & 3 \\
Cerai Hidup & 3 & 50 \\
Cerai Mati & 2 & 50 \\
\hline Status Pekerjaan & & \\
Tidak Bekerja & 38 & \\
Bekerja & 38 & \\
\hline
\end{tabular}

Berdasarkan tabel 1, menunjukkan kelompok umur responden dengan frekuensi terbanyak ada pada kelompok umur 35-45 tahun yaitu sebanyak 20 orang $(26 \%)$. Jumlah responden dalam penelitian ini berdasarkan jenis kelamin laki-laki dan perempuan masing-masing berjumlah 38 orang $(50 \%)$. Latar belakang pendidikan responden sebagian besar menyelesaikan peddidikan SMA/SMK sebanyak 32 orang (42\%). Berdasarkan status perkawinan maka diperoleh karakteristik responden dengan halusinasi pendengaran pada penelitian ini didominasi status kawin 49 orang (64\%). 
Claudia Wuri P., dkk : Pengaruh Cognitive Behavior Therapy Terhadap Penurunan Tingkat Kekambuhan Halusinasi Pada Pasien Halusinasi Dengar

Status pekerjaan pada penelitian ini berjumlah seimbang antara responden dengan yang tidak bekerja dan yang bekerja yaitu masing-masing berjumlah 38 orang $(50 \%)$.

Tabel 2.

Pengaruh Cognitive Behavior Therapy Terhadap Penurunan Tingkat Kekambuhan Halusinasi Pada Pasien Halusinasi Dengar

\begin{tabular}{|c|c|c|}
\hline Variabel & $\begin{array}{c}\mathrm{T}- \\
\text { Hitung }\end{array}$ & $\begin{array}{c}P- \\
\text { Value }\end{array}$ \\
\hline Rata-Rata Perbedaan & & \\
\hline $\begin{array}{c}\text { Halusinasi Dengar } \\
\text { Sebelum-Setelah } \\
\text { diberikan CBT }\end{array}$ & 16.21 & 0.000 \\
\hline
\end{tabular}

Hasil uji paired-t pada nilai delta ratarata perbedaan halusinasi dengar sebelumsetelah diberikan CBT menunjukkan nilai tsebesar 16.21 dengan nilai $\mathrm{p}=0.000$ $(\alpha<0.05)$. Dapat disimpulkan bahwa terdapat pengaruh pemberian CBT terhadap penurunan kekambuhan halusinasi dengar.

\section{PEMBAHASAN}

Hasil penelitian yang dilakukan pada 76 orang responden diperoleh hasil setelah diberikan CBT menunjukkan sebagian besar pasien mengalami tingkat kekambuhan rendah sebanyak 62 pasien dengan persentase $81,58 \%$. Hasil uji t berpasangan diperoleh nila $p$ 0,000 $(\mathrm{P}<0,05)$. Dalam beberapa penelitian yang telah dilakukan sebelumnya diperoleh bahwa ada pengaruh yang cukup signifikan antara penuruan tingkat kekambuhan halusinasi dengan pemberian CBT. Penelitian Sarandria (2012), menunjukkan adanya perbedaan peningkatan pelaksanaan cara mengontrol halusinasi yang bermakna antara kelompok yang mendapat dan tidak mendapat CBT ( $p$ value $<0,05)$. Halusinasi menurun secara bermakna pada kelompok yang mendapat CBT (p-value $<0,05)$.

Studi pendahuluan yang dilakukan oleh Somers \& Queree (2007) di Boston University, Center for Psychiatric Rehabilitation, menguji kelayakan dan efek intervensi CBT menunjukkan tingkat kesembuhan peserta yang tinggi dengan program ini ditemukan, dengan sebagian besar melaporkan bahwa program itu menarik dan membantu mereka mengelola gejalanya. Tujuh belas peserta (81\%) menyelesaikan lebih dari $50 \%$ dari sesi program yang dijadwalkan (6 sesi atau lebih) dan telah ditandai sebagai terdampak untuk program ini. Peserta yang terkena menunjukkan penurunan yang signifikan secara statistik pasca perawatan halusinasi pendengaran. Keefektifan terapi ini telah dibuktikan penelitian Granholm et al. (2014), yang mengungkapkan bahwa dengan pemberian CBT pada pasien skizofrenia kronis dapat meningkatkan kemampuan koping, mengevaluasi pengalaman yang salah, pencapaian kognitif insight yang baik, meningkatkan fungsi sosial. Selain itu CBT juga telah terbukti efektif dalam mengobati gejala positif akibat resistennya individu terhadap obat-obatan skizofrenia. Selain itu, CBT juga memberi manfaat dan efek yang positif dalam menurunkan kejadian kekambuhan pada pasien gangguan jiwa.

\section{KESIMPULAN \\ Implikasi}

Penelitian ini menunjukkan bahwa terdapat pengaruh yang signifikan terhadap penurunan tingkat kekambuhan halusinasi dengar. Pemberian terapi CBT dapat menjadi salah satu alternatif terapi modalitas dalam keperawatan jiwa untuk menurunkan angka kekambuhan masalah halusinasi pendengaran.

\section{Keterbatasan}

Keterbatasan dalam penelitian ini adalah dimana peneliti tidak memandang penyebab kekambuhan yang pasien alami. Ada beberapa pasien kambuh disebabkan oleh perilaku minum obat yang tidak teratur dan keluarga belum mampu merawat pasien dengan benar.

\section{DAFTAR PUSTAKA}

Adrian. (2016). Perbedaan Tingkat Depresi Remaja Awal Ditinjau Dari Jenis Humor Yang Digunakan. Universitas Kristen Satya Wacana. Retrieved from https://repository.uksw.edu/bitstream/1 23456789/802010011_Full text.pdf 
Claudia Wuri P., dkk : Pengaruh Cognitive Behavior Therapy Terhadap Penurunan Tingkat Kekambuhan Halusinasi Pada Pasien Halusinasi Dengar

Beck, J. S. (2011). Cognitive Behaviour Therapy: Basic and Beyond (2nd ed.). New York: The Guilford Press.

Damaiyanti, M., \& Iskandar. (2012). Asuhan Keperawatan Jiwa. Bandung: Refika Aditama.

Granholm, E., Holden, J., Link, P. C., \& McQuaid, J. R. (2014). Randomized Clinical Trial of Cognitive Behavioral Social Skills Training for Schizophrenia: Improvement in Functioning and Experiential Negative Symptoms. J Consult Clin Psychol, 82(6), 1173-1185. https://doi.org/10.1 037/a0037098.Randomized

Kaplan, H. I., \& Saddock, B. J. (2010). Sinopsis Psikiatri Ilmu Pengetahuan Perilaku Psikiatri Klinis. Tangerang: Bina Rupa.

Komalasari, G., Wahyuni, E., \& Karsih. (2011). Teori dan Teknik Konseling. Jakarta: PT Indeks.

Sarandria. (2012). Efektifitas Cognitive Behavioural Therapy (CBT) Untuk Meningkatkan Self Esteem Pada Dewasa Muda. Universitas Indonesia.

Somers, J., \& Queree, M. (2007). Core information document on cognitivebehavioral therapy. Vancouver: Centre for Applied Research in Mental Health and Addiction (CARMHA) at Simon Fraser University.

Stuart, G. W., \& Laraia, M. T. (2009). Principles and Practice of Psychiatric Nursing (8th ed.). Missouri: Mosby, Inc.

WHO. (2017). Depression and Other Common Mental Disorders Global Health Estimates. Geneva. Retrieved from https://www.who.int/mental _health/management/depression/preval ence_global_health_estimates/en/

Yosep, I. (2009). Keperawatan Jiwa. Bandung: Refika Aditama. 